Available online at GSC Online Press Directory

GSC Biological and Pharmaceutical Sciences

e-ISSN: 2581-3250, CODEN (USA): GBPSC2

Journal homepage: https://www.gsconlinepress.com/journals/gscbps

(RESEARCH ARTICLE)

\title{
Flock ownership pattern of goats in Idah local government area of Kogi State, Nigeria
}

\author{
Oyewole Benjamin Osigbodi1 ${ }^{*}$, Egahi Joseph Ochoche ${ }^{2}$ and Akoh Augustine Adaji ${ }^{1}$ \\ ${ }^{1}$ Department of Animal Production Kogi State University, Anyigba, Kogi State, Nigeria. \\ 2 Department of Animal Breeding and Physiology, College of Animal Science, University of Agriculture, Makurdi, Benue \\ State, Nigeria.
}

Publication history: Received on 25February 2020; revised on 12March 2020; accepted on 15March 2020

Article DOI: https://doi.org/10.30574/gscbps.2020.10.3.0050

\begin{abstract}
Questionnaires were used to obtain data on goat ownership from farmers, determine socio-economic characteristics of owners, identify management system, identify sources of stock and reasons for keeping goats in Idah Local Government Area (LGA) of Kogi State, Nigeria. One hundred (100) goat owners randomly selected from the council wards in the LGA were interviewed using questionnaires. Ninety-two (92) questionnaires were recovered from the field. Data collected included demographic information on the respondents, management practices, herd size, choice of management system, sources of feed and stock, and preference for a particular species. 58.7\% of the respondents were male while $41.3 \%$ female. $46.8 \%$ were married, 9.8\% widowed, $29.3 \%$ single and 14.1\% divorced. Most of the goat owners were between 20-30 years old (26.8\%), 22.9\% 31-40 years old, 10.9 51-60 years old. $8.7 \%$ had primary level education, $18.5 \%$ secondary school education and $37 \%$ tertiary education. Majority of the respondents (43.6\%) had herd sizes between $1-10$, with $83.7 \%$ of the goats being male and $75.1 \%$ female. Management system was mostly extensive (59.8\%). Patterns of housing for goats are the open space (53.3\%), low cost (18.3\%) and open type with run space (23.3\%). Choice of housing and management system is dueto low cost. Sources of feed for goats varied from crop residues (30.4\%), purchase (10.9\%), cut and carry (28.3\%) and a combination of crop residue and cut and purchase (30.4\%). $40.2 \%$ obtained their stock through purchase. It is concluded that goat rearing is practiced by all age groups and gender, most of whom were literate. Management system was mostly extensive due to its convenience in terms of labour and capital requirements.
\end{abstract}

Keywords: Flock; Goat; Idah; Demographic; Pastoralists; Questionnaire

\section{Introduction}

World population of goats was put at over 875.5 million by FAO in 2011 [1], while the report of National Agricultural Sample Survey cited by [2] said the population of goats in Nigeria was 72.5 million in 2011. [3] had asserted that 80$90 \%$ of the nation's livestock is in the hand of small holders or other traditional groups. According to [4] also opined that $99.97 \%$ of animals in Nigeria are traditionally managed, while [5] had reported a mean size of 6.2 goats per goat farmer in Anambra State, Nigeria. [6] had also reported that 72.6\% of goat owners in Oyo State, Nigeria had below ten (10) goats. Furthermore, [7] reported that there are 5.7 goats per compound in Nigeria. According to [8], any effort to raise the level of meat production in Nigeria must take into consideration farming communities. The Authors added that about $80-90 \%$ of cattle in Nigeria are in the hands of nomadic Fulanis or pastoralists, while sheep and goats are in the hands of small holder farmers (men, women and children) in Nigerian villages and peri-urban areas. Goats do not compete with humans, or poultry for food because they can subsist on forage alone and require little grain or concentrates for good production. Therefore, meat from small ruminants should be available at lower prices because of

\footnotetext{
* Corresponding author: Oyewole Benjamin Osigbodi
} 
their greater efficiency on no-grain diets than beef or pork and possibly poultry. Small ruminants produce about twice as much meat per animal unit in the tropics than cattle [9].

In Africa goats contributed 8.4\% total meat production, while they contributed $18.2 \%$ of the world total amount of milk [10]. [8] had reported that farmers in Ikenne Local Government Area of Nigeria fed their animals with kitchen waste and $74.7 \%$ fed cassava peels at least once a day, without including concentrate and mineral supplement in the diet of the animals. According to [11], small ruminants in tropical Africa are kept under traditional extensive systems. In the arid and sub-humid zones, cattle are reared with sheep and/or goats, while in the humid zone; they graze freely, with access to household and kitchen wastes when available. This study was necessary in order to generate and document baseline data on the flock ownership pattern for goat farmers in Idah Local Government Area of Nigeria, which would also serve as reference material for extension agents and farmers involved in planning and production of certified animals and animal products.

\subsection{Objectives of the study}

The objectives of the study were;

- To obtain baseline data on flock ownership pattern for goat in Idah Local Government Area of Kogi State.

- To determine the socio-economic characteristics of goat farmers in the area.

- To identify the management system of goats in the area.

- To identify sources of stock and reasons for keeping goats in the area.

\section{Material and methods}

The study was conducted in Idah Local Government Area of Kogi State, Nigeria. Idah lies on latitude $7^{\circ} 6^{\prime} 0^{\prime \prime}$ North, $6^{\circ}$ 44'0"East and has a total landmass of 36 km² [Map-Satellite images of Idah.http://www.mapland.cpm/nigeria/ kogi/Idah/Idah/, last accessed on 19/12/2019] characterized by tropical wet and dry climate. According to the 2006 census, the Local Government Area has a population figure of 79,815 [Nigeria Data Portal. https://nigeria.open dataforafrica.org/ifpbxbd/state-population-2006, last accessed 20/1/2020]. The Local Government, falls into the guinea savannah zone.

\subsection{Interviews}

Based on a formal questionnaire, interviews were conducted with 100 farmers randomly selected from the council wards in the Local Government Area. The respondents in all cases were the owners of goats. One hundred questionnaires were administered to respondents in the various wards of the Local Government Area, while 92 questionnaires were recovered from the field.

\subsection{Data collection}

The instrument used for data collection was structured questionnaires. Primary data was collected by the administration of structured questionnaires to the agro-pastoral farmers in the study area. Data collected included demographic information on the respondents, management practices used, flock and herd size, choice of management system, sources of feed and stock, and preference for a particular species.

\subsection{Data analysis}

The data collected were analyzed using descriptive statistics; frequencies and percentages using the Statistical Package for Social Sciences (SPSS) version 16.0.

\section{Results and discussion}

\subsection{Socio-economic characteristics of goat farmers in Idah local government area}

The results of the socio economic characteristics of small ruminant farmers are given in Table 1 and Table 2 . 
Oyewole et al. / GSC Biological and Pharmaceutical Sciences, 2020, 10(03), 118-125

Table 1 Socio-economic characteristics of goat farmers in Idah local government area

\begin{tabular}{|c|c|c|}
\hline Variable & Frequency & Percentage \\
\hline \multicolumn{3}{|l|}{ Age } \\
\hline $20-30$ & 23 & 26.8 \\
\hline $31-40$ & 21 & 22.9 \\
\hline $41-50$ & 21 & 22.9 \\
\hline $51-60$ & 10 & 10.9 \\
\hline $61 \&$ above & 17 & 16.5 \\
\hline Total & 92 & 100 \\
\hline \multicolumn{3}{|l|}{ Gender } \\
\hline Male & 54 & 58.7 \\
\hline Female & 38 & 41.3 \\
\hline Total & 92 & 100 \\
\hline \multicolumn{3}{|l|}{ Marital status } \\
\hline Single & 27 & 29.3 \\
\hline Married & 43 & 46.8 \\
\hline Divorced & 13 & 14.1 \\
\hline Widowed & 9 & 9.8 \\
\hline Total & 92 & 100 \\
\hline \multicolumn{3}{|l|}{ Level of education } \\
\hline No education formal & 12 & 13 \\
\hline Adult education & 21 & 22.8 \\
\hline Primary & 8 & 8.7 \\
\hline Secondary & 17 & 18.5 \\
\hline Tertiary & 34 & 37 \\
\hline Total & 92 & 100 \\
\hline
\end{tabular}

Table 2 Socio-economic characteristics of goat farmers in Idah local government area

\begin{tabular}{lll}
\hline Variable & Frequency & Percentage \\
\hline Years of keeping goats & & \\
$\leq 5$ & 23 & 25 \\
$6-10$ & 31 & 33.6 \\
$11-15$ & 19 & 20.7 \\
$16-20$ & 10 & 10.9 \\
$21-25$ & 7 & 5.5 \\
$26-30$ & 2 & 4.3 \\
Total & $\mathbf{9 2}$ & $\mathbf{1 0 0}$ \\
\hline
\end{tabular}




\begin{tabular}{|c|c|c|}
\hline \multicolumn{3}{|l|}{ Household size } \\
\hline $1-5$ & 32 & 34.9 \\
\hline $6-10$ & 49 & 53.3 \\
\hline $11-15$ & 9 & 9.8 \\
\hline $16-20$ & 2 & 2 \\
\hline Total & 92 & 100 \\
\hline \multicolumn{3}{|l|}{ Occupation } \\
\hline Farming & 23 & 25 \\
\hline Trading & 17 & 18.5 \\
\hline Artisan & 8 & 8.7 \\
\hline Civil service & 16 & 17.4 \\
\hline Teaching & 23 & 25 \\
\hline Others & 5 & 5.4 \\
\hline Total & 92 & 100 \\
\hline \multicolumn{3}{|c|}{ Years spent in occupation } \\
\hline $1-10$ & 45 & 49 \\
\hline $11-20$ & 30 & 32.7 \\
\hline $21-30$ & 8 & 8.7 \\
\hline $31-40$ & 7 & 7.6 \\
\hline $41 \&$ above & 2 & 2 \\
\hline Total & 92 & 100 \\
\hline \multicolumn{3}{|c|}{ Household monthly income } \\
\hline $10,000-20,000$ & 22 & 23.9 \\
\hline $21,000-30,000$ & 27 & 29.4 \\
\hline $31,000-40,000$ & 13 & 14.1 \\
\hline $41,000-50,000$ & 11 & 11.9 \\
\hline $51,000-60,000$ & 5 & 5.5 \\
\hline $61,000-70,000$ & 2 & 2.2 \\
\hline $71,000 \&$ above & 12 & 13 \\
\hline
\end{tabular}

\subsection{Socio-economic characteristics of the respondents}

Table1 and Table 2 show the socio-economic characteristics of the respondents in the sampled population. From the total number of ninety two (92) respondents, $58.7 \%$ were male while $41.3 \%$ were female. This observation is however at variance with earlier report by [12] that woman owned $60 \%$ of all small ruminants in tropical Africa. Observed results indicated that most of the goat farmers were married, that is, $46.8 \%$, while $9.8 \%$ were widowed, $29.3 \%$ were single and $14.1 \%$ were divorced. Most of the goat farmers (owners) were between $20-30$ years old $(26.8 \%), 22.9 \%$ for $31-40$, years old, 10.9 for 51-60 years old. This indicates that high proportion of the respondents involved in goat production were of the active age range. This may suggest that there is prospect for increased goat production in the area. It was observed that $8.7 \%$ of the farmers had primary level of education, $18.5 \%$ had secondary school education and $37 \%$ had tertiary education. Since a larger proportion of goat owners in the study area possess formal education, it is likely they will be open to new technologies/innovations in goat production. [13] reported similar findings. This also implies that there abound potentials for improved production practices since literate individuals within the active age groups are expected 
to be more receptive to new technological innovations. According to $[13 ; 14]$, education enables individuals to gain knowledge and skills and this increase their power of understanding.

Respondents are diversified in their occupations. The highest proportions of goat farmers in the area are farmers or teachers (25\%). This observation appears to indicate that it is more convenient for crop farmers and teachers to engage in rearing of goats than other forms of occupation. Crop farmers may have been encouraged to engage in goat farming as a mean of harnessing the generated crop residues, while more teachers may practice goat rearing due to the fact that they spend less number of hours at work than artisans, traders and civil servants.

Table 3 Flock size, sex and management system of goats in Idah local government area

\begin{tabular}{|c|c|c|}
\hline Variable & Frequency & Percentage \\
\hline \multicolumn{3}{|l|}{ Flock size } \\
\hline $1-10$ & 40 & 43.6 \\
\hline $11-20$ & 24 & 26.1 \\
\hline $21-30$ & 14 & 15.3 \\
\hline $31-40$ & 4 & 4.4 \\
\hline $41-50$ & 4 & 4.4 \\
\hline $51-60$ & 2 & 2.2 \\
\hline $61 \&$ above & 4 & 4 \\
\hline Total & 92 & 100 \\
\hline \multicolumn{3}{|c|}{ Number of male (adult) } \\
\hline $1-10$ & 77 & 83.7 \\
\hline $11-20$ & 10 & 10.9 \\
\hline $21-30$ & 2 & 2.2 \\
\hline $31-40$ & 3 & 3.3 \\
\hline Total & 92 & 100 \\
\hline \multicolumn{3}{|c|}{ Number of female (adult) } \\
\hline $1-10$ & 69 & 75.1 \\
\hline $11-20$ & 18 & 19.7 \\
\hline $21-30$ & 3 & 3.3 \\
\hline $31-40$ & 2 & 2 \\
\hline Total & 92 & 100 \\
\hline \multicolumn{3}{|c|}{ Number of kids } \\
\hline $1-5$ & 62 & 67.3 \\
\hline $6-10$ & 17 & 18.5 \\
\hline $11-15$ & 7 & 7.6 \\
\hline $16-20$ & 5 & 5.4 \\
\hline 21\& above & 1 & 1.1 \\
\hline Total & 92 & 100 \\
\hline
\end{tabular}


Table 4 Flock size, sex and management system of goats in Idah local government area

\begin{tabular}{|c|c|c|}
\hline Variable & Frequency & Percentage \\
\hline \multicolumn{3}{|l|}{ Sex of kids } \\
\hline Male & 14 & 15.2 \\
\hline Female & 21 & 22.8 \\
\hline Male \& Female & 57 & 62 \\
\hline Total & 92 & 100 \\
\hline \multicolumn{3}{|l|}{ System of management } \\
\hline Intensive & 9 & 9.8 \\
\hline Extensive & 55 & 59.8 \\
\hline Semi-intensive & 28 & 30.4 \\
\hline Total & 92 & 100 \\
\hline \multicolumn{3}{|l|}{ Pattern of housing } \\
\hline Low cost housing & 17 & 18.5 \\
\hline Open type housing with run space & 26 & 23.3 \\
\hline Open space housing & 49 & 53.3 \\
\hline Total & 92 & 100 \\
\hline \multicolumn{3}{|c|}{ Reason for choice of management system } \\
\hline Convenience & 21 & 22.8 \\
\hline Low cost of management & 33 & 35.9 \\
\hline More secured & 19 & 20.7 \\
\hline Tradition & 14 & 15.2 \\
\hline All the above reasons & 5 & 5.5 \\
\hline Total & 92 & 100 \\
\hline \multicolumn{3}{|l|}{ Sources of feed } \\
\hline Crop residue & 28 & 30.4 \\
\hline Purchase of feed & 10 & 10.9 \\
\hline Crop residue \& purchase of feed & 28 & 30.4 \\
\hline Cut and carry & 26 & 28.3 \\
\hline Total & 92 & 100 \\
\hline
\end{tabular}

\subsection{Flock sizes, sex and management system}

Table 3 and Table 4show flock size, sex and management system of goats in Idah Local Government Area. It was observed that majority of the respondents (43.6\%) had flock size between 1-10, with $83.7 \%$ of the goats being male and $75.1 \%$ female. It can be deduced that most of the goat farmers within the study area are not engaged in commercial farming of goats. This observation seems to confirm that the structure of the Nigerian livestock industry is such that 80 90 of the nation's livestock lies in the hands of small-holders or other traditional groups

[3]. [6] had earlier reported that most (72.6\%) goat farmers in Oyo State kept less than 10 goats. [5] reported a mean herd size of 6.2 in Anambra State. Observed result for sex ratio of goat is almost 1.11:1 for male to female. This may suggest that a number of these male goats may be put up for sale for meat production since they may not be required for breeding purpose.

Management systems adopted by goat farmers in the study location can be classified into three namely; intensive, semiintensive and extensive with percentage occurrence of $9.8 \%, 30.4 \%$ and $59.8 \%$ respectively. Extensive system was practiced by $59.8 \%$ of the farmers. Most of the goats in the area may therefore be exposed to adverse environmental conditions, theft, uncontrolled mating and accident among others. 
The patterns of housing for goats in the study area arethe open space (53.3\%), low cost (18.3\%) and open type with run space $(23.3 \%)$. The major reason for choice of housing and management system in the study area is low cost of management (35.9\%). The sources of feed for goats ranged from crop residues (30.4\%), purchase (10.9\%), cut and carry $(28.3 \%)$ and a combination of crop residue and cut and purchase $(30.4 \%)$.

Table 5 Sources of stock and reasons for keeping goats in Idah local government area

\begin{tabular}{lll}
\hline Variable & Frequency & Percentage \\
\hline Sources of stock & 30 & 32.6 \\
Inheritance & 37 & 40.2 \\
Purchase & 25 & 27.2 \\
Gift & $\mathbf{9 2}$ & $\mathbf{1 0 0}$ \\
Total & & \\
\hline Reasons for keeping goat & 18 & 19.6 \\
Easy to keep & 9 & 9.8 \\
Hardiness & 23 & 25 \\
High demand & 25 & 27.2 \\
Festivity & 17 & 18.5 \\
Prolificacy & $\mathbf{9 2}$ & $\mathbf{1 0 0}$ \\
Total & Field survey, 2018
\end{tabular}

\subsection{Sources and reasons for keeping of small ruminants by the respondents}

Table 5 shows the sources and reasons for keeping of goats by the respondents. The results obtained revealed that most of the goat farmers obtained their stock through purchase (40.2\%). However, $32.6 \%$ of the respondents acquired their stock through inheritance. Acquisition through gift was $27.2 \%$. The high proportion of acquisition through purchase may suggest high interest in goat keeping, due to some perceived potentials namely; store of wealth, festivity (27.2\%), high demand (25\%), prolificacy (18.5\%) and ease of keeping (19.6\%). In addition, it may also indicate that goats are highly valued in the study area.

\section{Conclusion}

It is concluded that goat rearing is practiced by all age groups and gender most of whom were literate. The production system mainly involved the extensive system of management. This practice was inherited and convenient in terms of labour and capital requirements. Goats were mainly reared for sale during festive seasons and due to high demand in the area. It is recommended that livestock improvement strategies for goat farming should be given attention to help upgrade goat production from the present peasantry level for better productivity and profitability. If achieved, this could go a long way in alleviating poverty particularly among the teeming populace.

\section{Compliance with ethical standards}

\section{Acknowledgments}

The authors wish to acknowledge the managements of Kogi State University Anyigba and University of Agriculture Makurdi Nigeria.

\section{Disclosure of conflict of interest}

The authors: Benjamin Osigbodi Oyewole, Joseph OchocheEgahi and Augustine AdajiAkoh hereby declare that there is no conflict of interest.

\section{Statement of informed consent}

The authors wish to state that informed consent was obtained from individual participants at the time of the survey. 


\section{References}

[1] Rodica C, Ion C and Carmen NG. (2013). Worldwide trends and orientation of raising goats. Munich Personal RePEc Archive, 53460, 1-8.

[2] Ogbeh A. (2016). Nigeria releases census of goats, sheep, pigs other livestocks in country. Premium Times.

[3] Olaloku EA. (1999). Sustainable animal production for self-sufficiency in the 21st century. In: Animal Science at the University of Ibadan: The way forward. 25th Anniversary Commemorate Brochure. De-Ayo Publishers, Ibadan, 29-44.

[4] Njoku PC. (2005). Development of quality assurance in Nigeria Livestock Industry. A paper presented at the 10th Annual Conference Animal Science Association of Nigeria, Ado Ekiti, 12-14.

[5] Gefu JO, Adu IF, AlawaCBI andMagaji SO. (1994). Characteristics of smallholder sheep and goat management practices in South East Nigeria: Observation from Anambra State. Nigeria Journal of Animal Production, 21(1\&2), 127-134.

[6] Adu AO, Famuyide OO, Adejoba OR, Oladele OI, Adeogun MO, Ojo MO and Sobowale MI. (2004). Demographic characteristics as correlates of sustained adoption of livestock technologies in Oyo State. Tropical Journal of Animal Science, 7 (2), 51-59.

[7] Otaru SM and Iyiola-Tunji AO. (2014).Small ruminant production and management techniques. Paper presented at National Workshop on "Strategies for improving livestock and fisheries extension service delivery for sustainable productivity" which was held at National Agricultural Extension and Research Liaison Services, Ahmadu Bello University, Zaria, Nigeria.

[8] Anaeto M, Tayo GO, Chioma GO, Ajao AO and Peters TA. (2009). Health and Nutrition Practices among Small holder Sheep and Goat Farmers in Ogun State, Nigeria. Livestock Research for Rural Development, 21(11).

[9] Terrill CE. (1983). Reproduction des ruminants en zone tropicale. Pointe-a-Pitre (F.W.I.), 8-10, June Ed. INRA Publ., 1984. In: Prospects for increasing Small Ruminant Production.

[10] Otchere EO, Ahmed HU, Adenowo TK, Kallah MS, Bawa ELK, Olorunju SA and Voh AA Jr. (1987). Sheep and goal production in the traditional Fulani agro-pastoral sector of Northern Nigeria. World Animal Review, 64, 50-55.

[11] Ademosun AA. (1989). Constraints and prospects for small ruminant research and development.

[12] FAO. (1991). Animal Production and Health paper 88. Food and Agriculture Organization of the United Nations: Rome, Italy.

[13] Garba Y and Muhammad IR. (2008). Sabara (Guiera senegalensis) as browse and a potential milk enhancer in ruminants in the semi-arid environment. Research Journal of Animal Science, 2(4), 123-127.

[14] Sodiya CI, Omotayo AM, Apantaku SO and Adedire MO. (2008). Socio-economic impact of some identified components of the agro pastoral production system in Ogun State, Nigeria. In: Adeyemi OA, Ogungbesan AM, Dada AO. Animal Agriculture towards Millennium Development in Nigeria. Proceedings of 33rd Annual Conference of Nigerian Society for Animal Production held at the College of Agricultural Sciences. Olabisi Onabanjo University, Ogun State, Nigeria, 33, 312-315.

\section{How to cite this article}

Oyewole BO, Egahi JO and Akoh AA. (2020). Flock ownership pattern of goats in Idah local government area of Kogi State, Nigeria. GSC Biological and Pharmaceutical Sciences, 10(3), 118-125. 